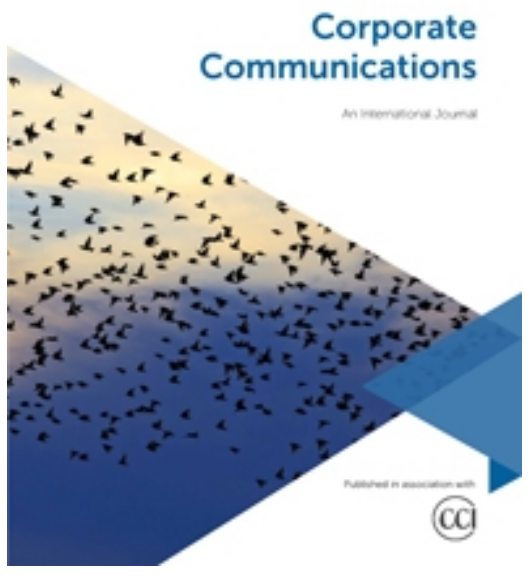

\title{
Challenges in stakeholders self-organising to enhance disaster communication
}

\begin{tabular}{|r|l|}
\hline Journal: & Corporate Communications: an International Journal \\
\hline Manuscript ID & CCIJ-07-2019-0078.R1 \\
\hline Manuscript Type: & Original Article \\
\hline Keywords: & $\begin{array}{l}\text { disaster communication, stakeholder communication, disaster } \\
\text { management, Communication management, Knysna Fire Disaster }\end{array}$ \\
\hline \multicolumn{2}{|l}{} \\
\hline
\end{tabular}

\section{SCHOLARONE ${ }^{\text {M }}$ \\ Manuscripts}




\section{Challenges in stakeholders self-organising to enhance disaster} communication

*Funding: No funding to be declared 


\title{
Challenges in stakeholders self-organising to enhance disaster communication
}

\begin{abstract}
ABTRACT
Purpose - This paper combines disaster risk reduction (DRR) and communication management literature to investigate the challenges and opportunities encountered when stakeholders spontaneously self-organise communication efforts during a disaster. The 2017 Knysna Fire Disaster in South Africa is used as context.
\end{abstract}

Research methodology - The qualitative, exploratory research was supported by data obtained through thematic analysis of qualitative in-depth interviews and the Facebook page created by the community. Information from the disaster debrief was also included.

Findings - The findings suggest that disaster information needs to be sent every 30 seconds to a minute to coordinate rescue and relief efforts. The challenges for disaster management teams to manage this mammoth task and the role that the self-organising community played in assisting the communication process was found not to be recognised in disaster management policies or systems. This adversely affected the work of the disaster management team and stakeholder relationship.

Research limitations - This study focussed on one disaster. Future studies could possibly compare various disaster examples to provide even greater insight into the self-organising communicative behaviour of those affected by disasters.

Originality/value - The research gives one of the first clear indications of the scope of disaster communication needed during a disaster. It also highlights the community's ability to contribute to communication management during a disaster, and which is not catered for in the practice, guidelines, or management systems used for disaster management.

KEYWORDS Disaster communication, Knysna Fire Disaster, Stakeholder communication, Disaster management, Communication management

Paper type Research paper 


\section{Challenges in stakeholders self-organising to enhance disaster communication}

\section{Introduction and purpose of the study}

Communities self-organising through social media during a disaster has been well documented. Some examples include 2005 Hurricane Katrina, 2007 San Diego wildfires, 2007 Virginia School Shooting, Sichuan 2008 earthquake, 2009 Red River Floods, 2010 Haiti earthquake, 2013 Influenza A Outbreak in China, and the 2013 Xavier snowstorm in Belarus (Nan and Lu 2014; Shkaruba et al. 2015; Villagra \& Quintana 2017).

Hobfoll (2012, in Williams and Sheperd 2016) support this phenomenon by declaring that the community "...have a phoenix-like tendency to re-emerge from the ashes of disaster and apparent defeat. Culture and survival depends on this". Delica-Willison and Gaillard (2012) agreed that communities collectively find solutions to challenges and are able to be a role player during a disasters. To this end, social media is used with greater regularity (Al-Taie and Ali 2017).

Although more research into communities' dynamic self-organisation and interaction with government during disasters are needed (Edelenbos et al 2018), some authors have started to highlight repeated themes that are emerging in such cases. Nan and Lu (2014) argued that the communities' self-organising online actions are mainly spontaneous, decentralised and uncontrolled. The activities were not specifically and proactively planned, but yet involved a large number of people and continued to evolve as new and relevant information became available.

When combining communities' resilience with the availability of social media like WhatsApp, Facebook, and Twitter, it could be argued that the previously regarded "helpless victims", have access to resources to make a communication contribution during a disaster. By using the strengths of the communities, they could support governmental disaster management efforts (Cole and Murhpy, 2014; Ng, 2016).

However, from a disaster management point of view, such community led initiatives could lead to a loss of disaster communication control and impede on institutions' limited resources as the community communicative actions falls outside of the formal disaster management structures. Issues like harnessing this resource, power distribution and managing accountability, needs more 
clarification (Delica-Willison and Gaillard, 2012; Jiang and Ritchie, 2017). Also a lack of trust, which is vitally important to facilitate the communication process between government and communities, would be further exasperated under the pressure of a disaster (Folke et al., 2005).

The aim of the study is therefore not to analyse the networking within the community, but rather by combining communication management and disaster risk reduction literature, gain insight into the process of how the self-organising community can be working collaboratively with disaster management. Given the above, the research objectives against the background of the 2017 Knysna Fire Disaster, South Africa, is to: (i) provide insight into the reasons why communities self-organise during a disaster by highlighting the challenges experienced by the various parties involved during the disaster, (ii) explore the challenges of this situation for efficient disaster management during the disaster, and (iii) to make recommendations based on the findings. The study follows a phenomenological approach operationalised through qualitative research methods.

\section{Literature study: disasters and community-led communication initiatives}

Input from disaster management and communication management theory is conceptually combined to frame the study within the systems paradigm. As a starting point key concepts are defined followed by a discussion on communication for community resilience, and an overview of the main guiding documents and frameworks for such a scenario.

\section{Defining key concepts}

The key concepts used in the study include crisis, disaster and community self-organisation.

- Differentiating between a crisis and a disaster

A crisis as viewed in communication management literature is an organisational event that “...threatens important expectancies of stakeholders related to health, safety, environmental, and economic issues, and can seriously impact an organization's performance and generate negative outcomes" (Coombs 2015). In contrast a disaster can be defined as the "....disruption of the life of a community; and ... is of a magnitude that exceeds the ability of those affected by the disaster to cope with its effects using only their own resources" (South Africa 2002). The UNISDR (2017) indicates that the impact of a disaster can be seen on human, material, economic and/or environmental level. 
- Defining community self-organisation

Community self-organisation is described as a process driven by the community rather than government in which the community drives the content and process of participation. It therefore differs from community development where the government organise and drive the community engagement. Community self-organisation, due to its uncontrolled nature, pushes government policy to newly define interaction and engagement with communities (Edelenbos et al. 2017). In essence communities push towards creating resilience.

\section{Communicative self-organising communities as an act of resilience}

In the field of disaster management the focus has shifted to disaster risk reduction (DRR) where there is a greater focus on preparedness, in order to create community resilience (Le Roux 2013). DRR practice refers to "...reducing disaster risks through systematic efforts to analyse and manage the causal factors of disasters, including through reduced exposure to hazards, lessened vulnerability of people and property, wise management of land and the environment, and improved preparedness for adverse events" (UNISDR 2013).

The DRR focus is strongly on pre-disaster conversations, assessments and actions with stakeholders like the community, to prepare for disasters and allow the community's resilience to disasters to grow. Activities like risk assessments are the starting point from where community resilience can be built. Within resilience building, a large focus is placed on collaboration with communities and using strengths from the communities to enhance their response capacity (Concern Worldwide 2015). 
Therefore community resilience refers to how well the community, as a system, can adapt their own structure, functions and identity, to the disaster event (Villagra \& Quintana 2017). In contrast a nonresilient community will be called vulnerable.

From this view resilience is seen as a characteristic that can continually be improved to provide those effected by a disaster with greater coping skills. It suggests that those effected are able to contribute to the DRR process. Within this definition it is clear that the communities at the heart of the disaster have a larger role to play in the preparation and management of the disaster.

In similar vain, Pitt and Treen (2016), who examined the points of communication failure in four disasters argued that it is an ongoing challenge to know how a disaster will influence communication plans. Their remedy to the situation is to suggest that "...ownership of the disaster plan should be devolved as broadly as possible in the community for which it is formulated". Such proactive communication management initiatives should be supported by policies (Gupta 2012).

It would seem that shared power between the community and government is implied. Specifically where governmental institutions are limited and there is some form of external threat (Edelenbos et al. 2018; Shkaruba et al. 2015). Traditional crisis and disaster management favour a centralised plan and control of the situation, which can guarantee fast decision making and resource allocation (Nan and Lu 2014). However, resilience seems to dictate that there should be an agreement of a degree of power sharing between the government and communities, similar to control mutuality (Hon and Grunig 1999). Unfortunately, most governmental approaches include developing a plan and then involving stakeholders to collaborate within these frameworks. "Complex social dynamics, such as trust building and power relations, have often been underestimated and the view of social relationships simplified" (Folke et al. 2005).

In the disaster situation where the community starts to self-organise, the government or emergency and disaster responders are not in control and dictating the communication flow of the event. This reaction from the community on the disaster is fuelled by their need for survival.

Edelenbos et al. (2018) define self-organisation as a concept deduced from systems thinking where new structures form out of chaos in order to create a new equilibrium. In addition the development of social media and communities engaging with the media, further challenges and disrupts the organised disaster management system in an effort to create equilibrium for the communities from 
Particularly interesting is to note the perseverance and commitment of the community members driving these efforts. Edelenbos et al. (2018) hinted that the organisers need to have a certain "...personality and tactical flexibility".

In contrast to the community actions, governments find it challenging to secure the long term participation of communities in DRR efforts in preparation for a disaster ( $O^{\prime} B$ rien et al. 2012). Additionally, the complexity of the division of responsibility among agencies and governmental levels involved in a disaster, challenge the productive involvement of the community (Managi and Guan 2017).

Spialek et al. (2016) argues that this focus on resilience in particular, creates opportunities for communication practitioners and scholars, as assistance with strategies to engage and build relationships with communities becomes increasingly important. This paper furthers the above argument to show that communication management can also contribute to community communication and collaboration during the disaster, by utilizing the community's communicative resilience.

Communication management literature advocates a pro-active approach to communication planning, combined with an inclusive stakeholder perspective that encourages collaboration and power sharing (Grunig et al. 2002; Steyn and Puth 2000). Stakeholder relationship management theory suggests that through transparent and ethical communication mutually beneficial, long-term relationships that balance the interests of all parties, and share power, can be built (Grunig et al. 2002). Similarly communication management advocates proactive stakeholder relationship building in an effort to build strong relationships built on trust, commitment and control mutuality as defined by Hon and Grunig (1999) and which can survive a pressured environment.

Communication practitioners could advice disaster management on how to create the elements of trust in a relationship by enhancing integrity, dependability and by showing competence. Particularly in disaster situations where the governmental abilities could be limited due to various reasons, the community is most strongly waiting for a show of competence and in its absence, will self-organise. 
The benefit to the stakeholder, as much as to the organisation, is considered an important outcome of the communicative effort (Ledingham 2003). It is argued that these foci can contribute greatly to the DRR field (Le Roux 2013; Le Roux 2014). However, accountability and guidelines for possible lifethreatening outcomes of the shared communicative efforts, as found in the disaster management arena, is less clear.

\section{Guiding documents and frameworks}

To assist and guide disaster management actions by governments, there are four global guiding frameworks applicable to this study, namely The Sendai Framework for Disaster Risk Reduction, the Hyogo Framework for Action (HFA), The UN's Resilient Cities Programme and The GNDR Indicators of Good Local Government. Overall these guidelines seem to suggest a focus on pre-disaster and/or post-disaster collaboration with communities. The in-disaster communicative value of the community is not clearly stipulated.

The guiding document in the disaster risk reduction field, The Sendai Framework for Disaster Risk Reduction 2015-2030 (UNISDR 2015), suggests a strong focus on pre-disaster cooperation between government and other stakeholders on issues like structures and policies. The aim of the collaboration is suggested to be on the creation of collaborative structures and policies in preparation for a disaster (UNISDR 2015). The Framework advocates that the particular government involved retain overall responsibility and accountability for the management of the disaster, thereby cementing their communicative power.

The predecessor of the Sendai Framework, the Hyogo Framework for Action (HFA), focuses strongly on the local application of disaster risk measures by appealing to governments to "...enhance and support disaster risk assessment and related processes" (UNISDR 2005). Both frameworks are supported by 180 countries under leadership of the United Nations. Although advocating a proactive approach, guidance on in-disaster community communication is not given.

The UN's Resilient Cities Programme provides a ten-point checklist to guide local government on community engagement. The checklist focusses on pre-disaster and post-disaster actions. It suggests that DRR should be based on community participation and that governments must build local alliances. Post-disaster governments are urged to put community needs at the centre of reconstruction (UNISDR 2012). The Global Network for Disaster Reduction (GNDR) indicators of good local government suggest that citizens should have insight into their DRR efforts through advisory 
In practice, the Incident Command System (ICS) is used as a globally recognised disaster management coordination system by various countries such as the USA, UK, Australia and recently adopted in South Africa (WCG 2013). The system is seen as a management method that brings stability in a disaster by coordinating all activities on behalf of the responsible government. The ICS extensively guides the communication during a disaster, and encourage communication from the ICS team to outside stakeholders through roles like the liaison officer. ICS planning does not currently allow for the community affected by the disaster to spontaneously manage a section of the ICS functions (like communication), unless it was pre-planned and integrated into the ICS system expost, and community members has to be trained in ICS (FEMA 2017).

Becker and Van Niekerk (2014) argue that although the South African disaster risk governance is one of the most forward thinking in the world, the execution of these frameworks are lacking. Van Niekerk $(2014 ; 2015)$ adds that in particular there are no clear practical guidelines for the lower levels of government (municipalities), who are in direct contact with the affected communities, when there is a need for "...strong community engagement" (Van Niekerk 2015). In addition, the South African Disaster Management Act No 57 of 2002, only encourage volunteer action if training was given before the disaster and the volunteers are willing to work in a structured environment. It is also suggested that municipalities should carefully manage the possibility of spontaneous and uncontrolled volunteer action.

The Amended Disaster Management Act (2015) has a stronger focus on community inclusion when referring to emergency preparedness, and expects Disaster Management to show how communitybased adaptation approaches will be included in their disaster management plan. There is no further clarity on how the spontaneous organising community can be included in the in-disaster scenario, with a push for the disaster management centres to plan for such behaviour in advance. 


\section{Context of the study}

Knysna is part of the tourist area, the Garden Route, in South Africa. From the 7 June 2017, for more than two weeks, a fire fuelled by storm winds raged, leading to the largest mobilisation of South African firefighters in the country's history (De Villiers, 2017). At times more than 26 separate fires were burning concurrently. More than 1100 houses were destroyed, with a further 385 houses and 69 schools left damaged by the fire. The death toll amounted to nine people. The South African National Defence Force provided 150 troops as security for vacated properties that could be looted, and to assist in water-bombing operations (BBC, 2017). In total 11 Oryx helicopters were used for water bombing at a cost of R13 million ( $\approx € 650000)$ because the typography of the landscape added to the complexities of fighting the fires.

The road leading into and out of Knysna had to be closed, making rescue and relief access almost impossible (Anon, 2017; Clarke and Joseph, 2017; Vegter, 2017). Some residents that were trapped by the fire, were moved by the National Sea Rescue Institute and volunteers via the sea to safety, whilst others sheltered on the beach. In addition to evacuating private residences, old age homes, hospitals and tourist accommodation also had to be evacuated.

In the chaos that ensued, communication cables and towers, and electricity cables were destroyed within the first few hours of the disaster, which disrupted municipal disaster communication to the community (Vegter, 2017). This rendered only social media and applications, like WhatsApp and Facebook, as communication tools.

The Knysna Fire was classified as a disaster in its early stages, and as such the government had to take the lead and responsibility in the disaster management efforts by means of the actions of the Disaster Management Centre and municipalities involved.

The government structures involved in this disaster was the Western Cape Provincial Government, the Eden District Municipality, and the Knysna Local Municipality. At the time of the Knysna Fire, the Western Cape Provincial Government was facing six further disasters including local service delivery protests and a severe drought.

A few days before the fire, a strong winter storm hit the municipality with high winds, lightning, and rough seas, which resulted in collapsing homes, fires and fatalities (BBC 2017). The storm hit Cape 
Town first and then continued to batter the rest of the municipal area. The strong winds from this storm played a significant role in the Knysna Fire disaster (Aljazeera 2017). At the time of the storm, approximately 10000 people, out of a population of 77000 , had to be evacuated from their homes in Knysna (BBC 2017). A government facing more than one disaster, with limited communication capability, seems to be the scenario that municipalities have faced before during disasters, and such a situation is frequently described in DRR literature.

The disaster management centre for the Knysna area, is situated in the Eden District Municipality, which is located in George, a town close to Knysna. The Knysna Local Municipality played a key role in the Knysna Fire Disaster, as they were closest to the communities involved.

\section{Research method}

A phenomenological approach was used in order to understand the lived experience from those involved in managing and co-ordinating the community social media reaction to the 2017 Knysna Fire Disaster, in order to extract the universal characteristics of the phenomenon (Hillman and Radel 2018; Taylor et al. 2015).

A qualitative research strategy allowed the research sufficient flexibility to explore the topic under investigation, understand the complexities of the situation, and provide sufficient information to answer the research questions. In particular semi-structured interviews, content analysis and participant observation was used. Using these flexible and dynamic research methods allowed the researcher sufficient time to explore the research topic to produce descriptive data that develop insight on how people acted and thought, as well as take practical considerations of accessing people otherwise not available, into account (Taylor et al. 2015).

The research approach and strategy dictated that a small number of information rich participants were needed that could provide insight into the research topic (Hillman and Radel 2018; Taylor et al. 2015). The interview schedule was conducted based on the themes identified in literature. The semistructured interviews allowed for questions to be rephrased and further delve into detail as necessary. The interviews provided sufficient data and reached data saturation (Taylor et al. 2015). The interviews were conducted in August 2017, just more than 2 months after the fire, which ensured that the experience was still vivid in the interviewees' minds. 
The interviewees included the Disaster Manager, Communication Manager, two Communication Officers and two Communication Interns who formed the communication team that worked on the disaster from the Eden Municipality. The Communication Officer from the Knysna Municipality was also included as the main source of information from this municipality to the community. All those with responsibility for communication during the disaster from municipal and district municipality level were included in this sample. Qualitative studies does not require large sample as the depth of the data provides the richness that is sought for insight. The interview data was analysed through thematic analysis. The themes were distilled from the data and within the larger framework of the literature conceptualisation.

To incorporate the view from the community, in-depth interviews with the two community members that originated a Facebook page central in self-organising the community, was done. In addition, content analysis of the first month's (June-July 2017) content on this Facebook page was included. The content analysis provided triangulation with the data given by the community interviewees, and supported the findings as interpreted from the community's point of view.

The researchers also attended the debriefing of the disaster from 31 July to 1 August 2017 held in Cape Town, organised by the Western Cape Provincial Disaster Risk Management Centre, to further understand the context of the disaster. Various players that were involved in the disasters managed by this specific disaster management centre, presented their insights with panel discussions and conversations. As participant observers the researchers were able to gain a greater understanding of the complexities of the situation and context of the disaster that assisted in the interpretation of the results (Hillman and Radel 2018).

\section{Findings}

The findings will be discussed according to the themes identified in literature.

\section{Challenges in disaster management as motivation for community self-organisation}

From a DRR view that advocates pro-activeness and a structured approach to managing a disaster, it was clear that the Knysna Local Municipality was under immense strain during the disaster. In a disaster like the Knysna Fire, the Local Municipality may opt to manage the disaster from their own local JOC with support from the District Municipality, which was done in this case. This decision 
could be argued to have political influence as the municipality could show their worth. Although having the JOC closer to the disaster to facilitate quicker firefighting reaction could have been argued to negatively impact communication to the community, as the municipalities limited communication resources were even further stretched. Facing issues such as limited capabilities during a disaster is expected, however, it motivates the need for greater community action for resilience, as motivated by authors such as Edelenbos et al. (2018), Nan and Lu (2014) and Theocharis et al. (2017).

The municipalities managed the disaster from the regulatory guidance given, but faced practical difficulties in collaborating with the spontaneous self-organising community. Especially given that the way in which the community self-organised could not have been predicted in advance. The community members who ran the Facebook page admitted that it would not have been something they would have considered beforehand. Therefore, even the requirements from the Amended Disaster Management Act (2015) to proactively plan for such events, in practice, was challenging.

\section{Challenges for communication management as motivation for community self-organisation}

Regarding communication channel management and information flow, the Western Cape Local Government specifically remarked on the importance of using both traditional and social media in combination during disasters. The Local Government reiterated the importance of early warning messages to communities and that two-way information flow, without referring to it being symmetrical or not, should be encouraged. However, they confirmed that in practice these ideals were hard to reach due to the challenges experienced during the disaster.

The Local Municipality faced serious communication challenges from very early on in the disaster. Their usual communication channels included a presence on Facebook, Twitter and a Municipal App. However, when all telephone communication were lost early in the disaster, the municipality had to ask the community to contact them by sending messages through Facebook Messenger as emergency response. These messages were then relayed to the JOC (Joint Operations Centre) manually. After a decision was made for action by the JOC, the written message was fed back to the community member via Facebook Messenger. The communication practitioner mentioned that "...social media was going crazy...", as they tried to manage the situation. From a disaster management perspective this was problematic as there would be no clear record of disaster related calls and actions, impacting on accountability. This in return would negatively impact the community's view of municipal competence (Hon and Grunig 1999). 
The municipal communication teams had to respond to a large number of media and other messages and facilitate numerous queries. This kept them from initiating information on logistical arrangements for relief donations and this information was only made available from 3 days after the disaster. In addition, the disaster management team first priority was to contain the disaster and information on a clear procedure for the handling and monitoring of donations was not immediately made available. As indicated before, this once again allows room for the community to self-organise.

Although communication professionals took the lead for communication during the disaster, the challenges they had to overcome severely impacted their ability to showcase their strategic worth.

The Disaster Management Centre located at the Eden District Municipality, makes use of the communication services of the district municipal communication practitioners. These practitioners have to continue with their day-to-day job and facilitate the disaster communication. In addition, the communicators were not specifically trained in the ICS system used. However, they do know that communication should be involved from a very early stage in the disaster and play a central role in contributing to response, rescue and recovery. Both the Centre and the practitioners tried to be as proactive as possible within the constraints they experienced.

At the time of the disaster the Local Municipality did not have an appointed Communication Manager, and the Communication Officer was assisted by a Communication Intern. When keeping in mind the amount of information that needs to be communicated during a disaster, the municipality needed communicative support.

From the interviews it was clear that both municipalities and in particular the communication practitioners was under immense pressure during a situation that was foreign to them, and which combined the worst case scenarios in terms of losing established means of communication with stakeholders.

On a positive note, the practitioners remarked that the disaster lead community members not active on social media to become active participants as a result of the disaster. The local municipality's Facebook page numbers increased from 5000 to 10000 members during the disaster. 


\section{Profiling the lead community members}

Before the disaster the husband and wife team that set up the Knysna Fire 7 June 2017 Facebook page, was well ingrained in the Knysna society and included in various WhatsApp groups for the area, specifically a women's WhatsApp group that also included the mayor. They have business interests in the area and showed clear commitment for the area and community to thrive.

Their actions to create a Facebook page came from them wanting to make a contribution during the disaster in order to assist the community. They realised that there was a need to consolidate information from various Facebook, Twitter and WhatsApp groups, to a centralised place for the community to be able to access information in a more structured way. This aligns clearly with the view that the community was trying to reach equilibrium in a chaotic environment (Arendt and Alesch 2015; Nan and Lu 2014).

Apart from coordinating disaster related information, the team also tracked financial donation schemes that were set up on social media pages, due to the risk of opportunistic individuals trying to exploit on the situation. They asked pages like Back-a-Buddy to verify the intentions of those that created the requests and "...some of the pages were taken down as they were found to be bad guys."

In agreement with Edelenbos et al. (2018), the lead community members were able to, under great pressure, to be flexible in working with various parties to collate information, and showed unique personal characteristics such as commitment, an embedded interest, dedication and a strong moral obligation. Through communication, the actions from a few individuals were able to improve the resilience of a larger community, by enabling the community to adapt to the event (Villagra \& Quintana 2017).

\section{A description of communicative self-organisation by the community}

The Knysna Fire 7 June 2017 Facebook page is an artefact that represents community's striving for resilience during a disaster.

Both the interview with the community members and Facebook analysis confirmed that the in the first 3 days the page focussed most on relaying information from people on the ground, directing firefighters, evacuation messages, distress calls, updates on fire spread, and posts on animal welfare. Some information on disaster aid and relief coordination of distribution points were noted. 
On the second day, posts focussed on the above and also messages of support for those affected by the disaster, sharing messages, photos and official letters. On the third day posts highlighted information on fires that were still burning, coordinating donations and relief aid, reuniting owners and pets, searches for missing persons, and organising and bringing together people wanting to volunteer. Practical information on immediate assistance people could get from insurance companies was also shared, together with contact details of the municipality. At this point the Airbnb disaster tool was also activated. On the Facebook page appreciation for firefighters are also shown and received great reaction. Another favourite was the map updates that were created by volunteers on the ground in the area.

After 2 weeks the page turned more to donation and relief coordination to show the community needs. There was also a strong focus on messages of hope and future activities and tourist incentives to rebuild the area. The page also provided a space where people could discuss reports on the fire candidly.

Through their own research the respondents suggested that many relief organisations reacted from information on their page, without being active on the page. In addition they found that a large number of the donations received, were made based on what people saw on the Facebook page. As shown by the respondents, impact of immediate and clear communication during a disaster, cannot be emphasised strongly enough.

The respondents set up a trust account to which donations could be made and in which people could specify the goals that the donation needed to be used for. They regularly reported on the progress of this account and the bank statements were regularly made available on their Facebook page.

\section{Community self-organising influence on stakeholder relationships}

The respondents were keen to verify information with the JOC before posting it on their Facebook page and engage with the municipality, but found the process to slow and cumbersome and proceeded without JOC approval. The relationship between the municipality and community groups deteriorated as the disaster progressed and the respondents were informed that the municipality were "...not happy about the page".

The municipality took note of the social media pages initiated by the community over which they had no control. They however, stated strongly that it was seen as their responsibility to organise the 
rescue and relief effort with the community organisations involved, by being the link between donations and receivers, as per the Disaster Management regulations.

The result was that both parties in the strained relationship to some extent stopped involving the other in their communication attempts stifling all collaboration. Although Edelenbos et al. (2018) argued that they found governments to be positive about community self-organisation initiatives, it was not the case in this instance. This could be attributed to various issues, such as the pressure under which the municipalities had to operate, the lack of clear guidelines on how to involve spontaneous community self-organisation while still retaining the responsibility, or historical mistrust in the relationship.

Interestingly in this case the community members were more positive than the governmental entities to have a collaborative relationship during the disaster. The respondents suggested that having community members involved in communication coordination could assist the municipalities, as the community members can "...work around red tape, where the municipality cannot".

The respondents suggested that it was in the disaster management team's interest that community members had vested interest in good communication flow during the disaster. The respondents found that trust could also be created in messaging as the information is found to be timeous, helpful and accurate.

\section{Speed at which in-disaster communication needed to flow}

Although it is agreed that communication should flow fast from the disaster managers to those affected, the speed and vastness of information flow has not been specifically mentioned in literature.

During this disaster the communication flow at Local Municipality level seemed particularly slow, due to the process that had to be followed. The Joint Operations Centre (JOC) needed to meet and then a situational report was produced from which the media, and through the media, other stakeholders were informed twice daily.

To reach the local community the municipal communication practitioner noted that information changed rapidly and that social media had to be updated "...every 10 minutes..." with new information. The municipality did not have any social media software to assist them in managing the situation. 
The community's view on the speed at which new information needed to be circulated was different from that suggested by the municipalities. The community argued that the need for regular updates was necessitated by the constantly changing disaster situation.

The amount of information posted to the centralised Facebook Page was vast. One respondent noted: "...at the start of the disaster the page was updated every 30 seconds to 1 minute, with more than 640 posts for the first day alone". Up until day 40 they posted more than 2500 times. The volume was so great that it alerted Facebook and the posts were taken down. The respondents had to contact Facebook to explain the situation to be able to continue sending out information. Due to this some of the initial posts could not be retrieved for analysis.

In addition, the respondents dealt with more than 1500 Facebook Messenger messages a day, over and above the WhatsApp calls and messages they received.

It is clear that the vast task of sending timeous information out during a disaster, would be difficult for a disaster management team that might already be under pressure due to various other challenges they are facing. It would seem that there is a ripe opportunity for communities to assist in this sphere of disaster management by spontaneously self-organising disaster related communication, preferably in collaboration with the disaster management actions.

\section{Discussion, recommendations and conclusion}

The study reiterated what was found in previous studies: that communities will strive to survive disasters (Hobfoll 2012, in Williams and Sheperd 2016).

One of the main contributions of this research is that it gives one of the first clear indications of the speed and scope of communication needed during a disaster. The finding further suggests that the communication expectation during a disaster is much bigger than previously anticipated. If assumed that messages need to be sent out every 30 seconds to a minute, it becomes clear that a very robust, proactive communication team and communication channels needs to be in place and trained before a disaster. It remains problematic that the messages need to be sent out quicker than what the JOC process and disaster management process can facilitate. It would seem that the development of spontaneous communicative self-organisation of communities could possibly relate 
to this challenge. However, these community groups could also be an untapped resource for disaster management teams, given that a way of working together where accountability according to the regulatory frameworks stays with the governmental institutions, can be found.

Various challenges to disaster management was mentioned. The study highlighted the need for a robust, trusting relationship between municipalities and communities before a disaster hits. It seemed that there were little understanding between the municipality and community in terms of their roles and responsibilities during the disaster, which proved detrimental to their relationship. The community interpreted the lack of information from the government as a lack of involvement and willingness to assist. The municipalities also did not expect that communities could contribute to the disaster management effort, leading to them trying to gain control offer the community's selforganisation efforts. These views negatively influenced the trust relationships and the disaster management efforts.

From the research it can be argued that the characteristics of such community leaders should display a motivation for resilience creation for the whole community. This highly motivated resource need to be recognised.

Communication professionals could play a positive, strategic role in guiding relationship building as preparation for disaster management and part of increasing community resilience (Gupta 2012). Such activities would align with the guidelines from the Amended Disaster Management Act (2015). The recommendations from this study includes that a proactive approach to the phenomenon needs to be developed and followed. This proactive approach would unfold on two levels:

- Firstly, on DRR policy and framework level, the willingness and ability of community volunteers to assist with communication actions during a disaster should be acknowledged. The Amended Disaster Management Act 2015 to some level hints toward this, but still does not provide best practice guidelines. Frameworks and standards for the management of disasters should incorporate the opportunity for community members to spontaneously contribute during the disaster, and not only in resilience building before, or rehabilitation efforts after the disaster. Providing formation on this issue, and adding more research to highlighting the phenomenon to the UNISDR, could see it taken up into the next Framework for DRR. On an operational level, the ICS system could be expanded to allow for community 
members to join the process - even when not pre-trained in the system. More detail on how this can be done need to be investigated and negotiated.

- Secondly, local municipalities and disaster management centres need to be able to incorporate community self-organisation into their disaster management efforts. However, this can only be done when strong relationships, in which there is trust, is built between the community and municipality pre-disaster as an ongoing stakeholder relationship management effort. Currently disaster management centres make use of Advisory Forums to engage with various stakeholders, including the community. This research suggests that more engagement than the Advisory Forums is needed. Since it is hard to predict which community members will be able to assist during a disaster, these stakeholder relationships needs to run deep and wide into the community.

It could beneficial for local municipalities or disaster management centres, as part of their relationship building efforts pre-disaster, (i) to draft engagement rules with stakeholders that incorporate their expectations of each other pre-, in- and post-disaster, (ii) create a framework on disaster communication involvement from the community that could guide future actions, and (iii) agree on a basic collaborative communication plan for a disaster.

- Lastly, a communication practitioner understanding the possibilities and challenges of spontaneous community communication during a disaster, could assist in enacting a strategic role by pro-actively advising the disaster management team on issues.

\section{Research limitations and suggestions for future research}

Bean (2018) motivates for research on communication in disasters as "vitally needed", and argues that the results can contribute to further community resilience. Although this study only focussed on one disaster, the trend of the disaster "victims" providing a valuable communication resource need to be further explored to provide clear policy frameworks and best practice.

Future studies could compare various examples of community self-organisation of communication during disasters, and test best practice suggestions to reach a prescribe code of practice. Including large scale studies viewing this phenomenon from a community perspective would also illuminate 
the constraints of those affected by disasters and their motivation for action and selection of action routes to take. Network theory could also be used to understand the spontaneous development of community leaders that drive community self-organisation efforts. 


\section{References}

Aljazeera. (2017), "Storm kills several, displaces thousands in Cape Town", available at:

https://www.aljazeera.com/news/2017/06/storm-kills-displaces-thousands-cape-town-

170608052748704.html (accessed November 12, 2017).

Al-Taie, M.Z. and Ali, A. (2017), "A self-organizing communication model for disaster risk management", International Journal of Advanced Soft Computing Application, Vol. 9 No. 2, pp. 1730.

Anon. (2017), "About: The Garden Route Rebuild", available at:

https://www.gardenrouterebuild.co.za/about/(accessed November 12, 2017).

Arendt, L. A., \& Alesch, D. J. (2015). Long-Term Community Recovery From Natural Disasters, CRC Press, Boca Raton.

BBC. (2017), "South Africa: 10,000 Knysna residents evacuated amid fire", available at:

https://www.bbc.co.uk/news/world-africa-40199270(accessed November 12, 2017).

Bean, H. (2018), “National resilience”, Journal of Applied Communication Research, Vol. 46 No 1, pp. 23-25.

Becker, P. and Van Niekerk, D. (2014), "Developing sustainable capacity for disaster risk reduction on Southern Africa", in Schroder, J. Hazards, Risks, and Disasters in Society, Elsevier, Amsterdam, pp. $63-78$

Clarke, H. and Joseph, E. (2017), "Unprecedented' bush fires in South Africa leave 9 dead", available at: https://edition.cnn.com/2017/06/08/world/south-africa-fires/ (accessed November 12, 2017).

Cole, J.M. and Murhpy, B.L. (2014), "Rural hazard risk communication and public education: Strategic and tactical best practices", International Journal of Disaster Risk Reduction, Vol. 10, pp. 292-304.

Concern Worldwide. (2015), “Disaster Risk Reduction for Community Resilience: A synthesis of lessons from more than a decade of Disaster Risk Reduction Programming", available from: 
https://doj19z5hov92o.cloudfront.net/sites/default/files/resource/2015/12/disaster risk reduction for community resilience.pdf (accessed November 12, 2017).

Coombs, W.T. (2015). Ongoing crisis communication: Planning, managing and responding, Sage, Thousand Oaks, California.

De Villiers, J. (2017), “Knysna fire led to largest deployment of firefighting resources in SA history authorities", available at: https://www.news24.com/SouthAfrica/News/knysna-fire-led-to-largestdeployment-of-firefighting-resources-in-sa-history-authorities-20170620 (accessed November 12, 2017).

Delicia-Willison, Z. and Gaillard, J.C. (2012), "Community action and disaster", in Wisner, B., Gaillard, J.C. and Kelman, I, The Routledge Handbook of hazards and disaster risk reduction, Routledge, Oxon, pp. 711-722.

Edelenbos, J., Van Meerkerk, I. and Koppenjan, J. (2017), "The challenge of innovating politics in community self-organization: the case of Broekpolder", Public management review, Vol. 19, No. 1 , pp. 55-73.

Edelenbos, J., Van Meerkerk, I. and Schenk, T. (2018), "The evolution of community self-organization in interaction with government institutions: cross-case insights form three countries", American review of public administration, Vol. 48, No. 1, pp. 52-66.

FEMA. (2017), “National Incident Command System”, available at: https://www.fema.gov/medialibrary-data/1508151197225-ced8c60378c3936adb92c1a3ee6f6564/FINAL NIMS 2017.pdf (accessed November 12, 2017).

Folke, C., Hahn, T., Olsson, P. and Norberg, J. (2005), “Adaptive governance of social-ecological systems", Annual Review of Environmental Resources, Vol. 30, pp. 441-473.

Grunig, L.A., Grunig, J.E. and Dozier, D.M, (2002), Excellent public relations and effective organizations: a study of communication management in three countries, Lawrence Erlbaum, Mahwah, NJ. 
Gupta, M. (2012), "Settlement and shelter reconstruction", in Wisner, B., Gaillard, J.C. and Kelman, I, The Routledge Handbook of hazards and disaster risk reduction, Routledge, Oxon, pp. 553-565.

Hillman, W. and Radel, K. (2018), Qualitative methods in tourism research: Theory and practice, Channel view publications, Bristol.

Hon, L.C. and Grunig, J.E. (1999), Guidelines for measuring relationships in public relations, Institute for Public Relations (IPR), available at https://instituteforpr.org/measuring-relationships/ (accessed November 12, 2017).

Jiang, Y. and Ritchie, B.W. (2017), "Disaster collaboration in tourism: Motives, impediments and success factors", Journal of Hospitality and Tourism Management, Vol. 31, pp. 70-82.

Le Roux, T. (2013), "An exploration of the role of communication during the in-crisis situation", Jàmbá: Journal of Disaster Risk Studies, Vol. 5 No. 2, pp. 1-9.

Le Roux, T. (2014), "DR ${ }^{4}$ communication in the South African context: A conceptual paper", Public Relations Review, Vol. 40 No 2, pp. 305-314.

Ledingham, J.A. (2003), “Explicating relationship management as a general theory of public relations", Journal of Public Relations Research, Vol. 15 No. 2, pp. 181-198.

Managi, S. and Guan, D. (2017), “Multiple disasters management: Lessons from the Fukushima triple events", Economic Analysis and Policy, Vol. 53, pp. 114-122.

Nahem, J. (ed). (2009), “UNDP: A user's guide to measuring local governance", available at: http://www.undp.org/content/dam/aplaws/publication/en/publications/democraticgovernance/dg-publications-for-website/a-users-guide-to-measuring-local-governanceLLG\%20Guide.pdf (accessed November 12, 2017).

Nan, N. and Lu, Y. (2014), "Harnessing the power of self-organization in an online community during organizational crisis", MIS Quarterly, Vol. 38, No. 4, pp.1135-1157, Dec. 
$\mathrm{Ng}$, S. (2016), "Governance beyond the government: responding to a reactionary flood governance regime in Ayutthaya, Thailand", Habitat International, Vol. 52, pp. 11-19.

O’Brien, G., Bhatt, M., Saunders, W., Gaillard, J.C. and Wisner, B. (2012), “Local government and disaster", in Wisner, B., Gaillard, J.C. and Kelman, I, The Routledge Handbook of hazards and disaster risk reduction, Routledge, Oxon, pp. 629-640.

Pitt, C.S. and Treen, E. (2016), "Understanding communication in disaster response: A marketing strategy formulation and implementation perspective", Journal of Public Affairs, Vol. 17 No. 3, pp. 17.

Shkaruba, A., Skryhan, H. and Kireyeu, V. (2015), "Sense-making for anticipatory adaptation to heavy snowstroms in urban areas", Urban Climate, Vol. 14, pp. 636-649.

South Africa. (2002), Disaster Management Act, 2002 (Act 57 of 2002), Government Printer, Pretoria.

South Africa. (2015), Amended Disaster Management Act, 2015, Government Printer, Pretoria.

Spialek, M.L., Czlapinski, H.M. and Houston, J.B. (2016), "Disaster communication ecology and community resilience perceptions following the 2013 Illinois tornados", International Journal of Disaster Risk Reduction, Vol. 17, pp. 154-160.

Steyn, B., and Puth, G, (2000), Corporate communication strategy, Heinemann, Sandown.

South Africa (Republic). (2002). Disaster Management Act 57 of 2002. Pretoria: Government Printer.

Taylor, S.J., Bogdan, R. and De Vault, M.L. (2015), Introduction to Qualitative Research Methods: A Guidebook and Resource, John Wiley \& Sons, Hoboken, New Jersey.

Theocharis, Y., Vitoratou, S. and Sajuria, J. (2017), "Civil society in times of crisis: understanding collective action dynamics in digitally-enabled volunteer networks", Journal of Computer-Mediated Communication, Vol. 22, pp. 248-265. 
UNISDR. (2005), “Hyogo Framework for Action 2005-2015: Building the Resilience of Nations and Communities to Disasters", available at:

https://www.unisdr.org/files/1037_hyogoframeworkforactionenglish.pdf (accessed November 12, 2017).

UNISDR. (2012), "The Ten Essentials for Making Cities Resilient Checklist Summary", available at: https://www.unisdr.org/files/26462 13.tenessentialschecklist.pdf (accessed November 12, 2017).

UNISDR. (2013), "United Nations Plan of action on disaster risk reduction for resilience", available at: https://www.preventionweb.net/files/33703 actionplanweb14.06cs1.pdf (accessed November 12, 2017).

UNISDR. (2015), "Sendai framework for disaster risk reduction 2015-2030", available at: https://www.preventionweb.net/files/43291 sendaiframeworkfordrren.pdf (accessed November 12, 2017).

UNISDR. (2017), "Terminology", available at:

https://www.unisdr.org/we/inform/terminology\#letter-d (accessed November 12, 2017).

Van Niekerk, D. (2014), "A critical analysis of the South African Disaster Management Act and Policy Framework", Disasters, Vol. 38 No. 4, pp. 858-77.

Van Niekerk, D. (2015), “Disaster risk governance in Africa: A retrospective assessment of progress against the Hyogo Framework for Action (2000-2012)", Disaster Prevention and Management, Vol. 24 No. 3, pp. 397-416.

Vegter, I. (2017), "Devastation in Knysna: a photo survey", available at:

https://www.dailymaverick.co.za/article/2017-06-09-devastation-in-knysna-a-photosurvey/\#.WzDydVVKiUk (accessed November 12, 2017).

Villagra, P. and Quintana C. (2017), “Disaster governance for community resilience in coastal towns: Chilean case studies", International journal of environmental research and public health, Vol. 14, No. 1063, pp.1-24. 
Western Cape Government (WCG). (2013), "Overview of the Incident Command System", https://www.westerncape.gov.za/text/2013/June/incident-command-system-overview-20-june2013.pdf (accessed November 12, 2017).

Williams, T.A. and Sheperd, D.A. (2016), "Victim entrepreneurs doing well by doing good: Venture creation and well-being in the aftermath of a resource shock", Journal of Business Venturing, Vol. 31, pp. 365-387. 


\section{Challenges in stakeholders self-organising to enhance disaster} communication

*Funding: No funding to be declared 


\title{
Challenges in stakeholders self-organising to enhance disaster communication
}

\begin{abstract}
ABTRACT
Purpose - This paper combines disaster risk reduction (DRR) and communication management literature to investigate the challenges and opportunities encountered when stakeholders spontaneously self-organise communication efforts during a disaster. The 2017 Knysna Fire Disaster in South Africa is used as context.
\end{abstract}

Research methodology - The qualitative, exploratory research was supported by data obtained through thematic analysis of qualitative in-depth interviews and the Facebook page created by the community. Information from the disaster debrief was also included.

Findings - The findings suggest that disaster information needs to be sent every 30 seconds to a minute to coordinate rescue and relief efforts. The challenges for disaster management teams to manage this mammoth task and the role that the self-organising community played in assisting the communication process was found not to be recognised in disaster management policies or systems. This adversely affected the work of the disaster management team and stakeholder relationship.

Research limitations - This study focussed on one disaster. Future studies could possibly compare various disaster examples to provide even greater insight into the self-organising communicative behaviour of those affected by disasters.

Originality/value - The research gives one of the first clear indications of the scope of disaster communication needed during a disaster. It also highlights the community's ability to contribute to communication management during a disaster, and which is not catered for in the practice, guidelines, or management systems used for disaster management.

KEYWORDS Disaster communication, Knysna Fire Disaster, Stakeholder communication, Disaster management, Communication management

Paper type Research paper 


\section{Challenges in stakeholders self-organising to enhance disaster communication}

\section{Introduction and purpose of the study}

Communities self-organising through social media during a disaster has been well documented. Some examples include 2005 Hurricane Katrina, 2007 San Diego wildfires, 2007 Virginia School Shooting, Sichuan 2008 earthquake, 2009 Red River Floods, 2010 Haiti earthquake, 2013 Influenza A Outbreak in China, and the 2013 Xavier snowstorm in Belarus (Nan and Lu 2014; Shkaruba et al. 2015; Villagra \& Quintana 2017).

Hobfoll (2012, in Williams and Sheperd 2016) support this phenomenon by declaring that the community "...have a phoenix-like tendency to re-emerge from the ashes of disaster and apparent defeat. Culture and survival depends on this". Delica-Willison and Gaillard (2012) agreed that communities collectively find solutions to challenges and are able to be a role player during a disasters. To this end, social media is used with greater regularity (Al-Taie and Ali 2017).

Although more research into communities' dynamic self-organisation and interaction with government during disasters are needed (Edelenbos et al 2018), some authors have started to highlight repeated themes that are emerging in such cases. Nan and Lu (2014) argued that the communities' self-organising online actions are mainly spontaneous, decentralised and uncontrolled. The activities were not specifically and proactively planned, but yet involved a large number of people and continued to evolve as new and relevant information became available.

When combining communities' resilience with the availability of social media like WhatsApp, Facebook, and Twitter, it could be argued that the previously regarded "helpless victims", have access to resources to make a communication contribution during a disaster. By using the strengths of the communities, they could support governmental disaster management efforts (Cole and Murhpy, 2014; Ng, 2016).

However, from a disaster management point of view, such community led initiatives could lead to a loss of disaster communication control and impede on institutions' limited resources as the community communicative actions falls outside of the formal disaster management structures. Issues like harnessing this resource, power distribution and managing accountability, needs more 
clarification (Delica-Willison and Gaillard, 2012; Jiang and Ritchie, 2017). Also a lack of trust, which is vitally important to facilitate the communication process between government and communities, would be further exasperated under the pressure of a disaster (Folke et al., 2005).

The aim of the study is therefore not to analyse the networking within the community, but rather by combining communication management and disaster risk reduction literature, gain insight into the process of how the self-organising community can be working collaboratively with disaster management. Given the above, the research objectives against the background of the 2017 Knysna Fire Disaster, South Africa, is to: (i) provide insight into the reasons why communities self-organise during a disaster by highlighting the challenges experienced by the various parties involved during the disaster, (ii) explore the challenges of this situation for efficient disaster management during the disaster, and (iii) to make recommendations based on the findings. The study follows a phenomenological approach operationalised through qualitative research methods.

\section{Literature study: disasters and community-led communication initiatives}

Input from disaster management and communication management theory is conceptually combined to frame the study within the systems paradigm. As a starting point key concepts are defined followed by a discussion on communication for community resilience, and an overview of the main guiding documents and frameworks for such a scenario.

\section{Defining key concepts}

The key concepts used in the study include crisis, disaster and community self-organisation.

- Differentiating between a crisis and a disaster

A crisis as viewed in communication management literature is an organisational event that “...threatens important expectancies of stakeholders related to health, safety, environmental, and economic issues, and can seriously impact an organization's performance and generate negative outcomes" (Coombs 2015). In contrast a disaster can be defined as the "....disruption of the life of a community; and ... is of a magnitude that exceeds the ability of those affected by the disaster to cope with its effects using only their own resources" (South Africa 2002). The UNISDR (2017) indicates that the impact of a disaster can be seen on human, material, economic and/or environmental level. 
At its most fundamental level, disasters are seen as large scale and require governmental response, but can overlap with a crisis (Coombs 2015). On a more philosophical level, the crisis situation differs from a disaster in that the aim of communication before, during and after the disaster is not aimed at limiting reputational damage, or viewed from an organisational or governmental standpoint. Rather, the view is to create survival and resilience by viewing the disaster from a situational or contextual viewpoint, to understand the roles that all those involved and affected can play to alleviate and resolve the situation (Le Roux 2013).

In this interdisciplinary field one could argue that communication management principles could assist disaster management with guidance on the community communication activities taking place during a disaster.

- Defining community self-organisation Community self-organisation is described as a process driven by the community rather than government in which the community drives the content and process of participation. It therefore differs from community development where the government organise and drive the community engagement. Community self-organisation, due to its uncontrolled nature, pushes government policy to newly define interaction and engagement with communities (Edelenbos et al. 2017). In essence communities push towards creating resilience.

\section{Communicative self-organising communities as an act of resilience}

In the field of disaster management the focus has shifted to disaster risk reduction (DRR) where there is a greater focus on preparedness, in order to create community resilience (Le Roux 2013). DRR practice refers to "...reducing disaster risks through systematic efforts to analyse and manage the causal factors of disasters, including through reduced exposure to hazards, lessened vulnerability of people and property, wise management of land and the environment, and improved preparedness for adverse events" (UNISDR 2013).

The DRR focus is strongly on pre-disaster conversations, assessments and actions with stakeholders like the community, to prepare for disasters and allow the community's resilience to disasters to grow. Activities like risk assessments are the starting point from where community resilience can be built. Within resilience building, a large focus is placed on collaboration with communities and using strengths from the communities to enhance their response capacity (Concern Worldwide 2015). 
Therefore community resilience refers to how well the community, as a system, can adapt their own structure, functions and identity, to the disaster event (Villagra \& Quintana 2017). In contrast a nonresilient community will be called vulnerable.

From this view resilience is seen as a characteristic that can continually be improved to provide those effected by a disaster with greater coping skills. It suggests that those effected are able to contribute to the DRR process. Within this definition it is clear that the communities at the heart of the disaster have a larger role to play in the preparation and management of the disaster.

In similar vain, Pitt and Treen (2016), who examined the points of communication failure in four disasters argued that it is an ongoing challenge to know how a disaster will influence communication plans. Their remedy to the situation is to suggest that "...ownership of the disaster plan should be devolved as broadly as possible in the community for which it is formulated". Such proactive communication management initiatives should be supported by policies (Gupta 2012).

It would seem that shared power between the community and government is implied. Specifically where governmental institutions are limited and there is some form of external threat (Edelenbos et al. 2018; Shkaruba et al. 2015). Traditional crisis and disaster management favour a centralised plan and control of the situation, which can guarantee fast decision making and resource allocation (Nan and Lu 2014). However, resilience seems to dictate that there should be an agreement of a degree of power sharing between the government and communities, similar to control mutuality (Hon and Grunig 1999). Unfortunately, most governmental approaches include developing a plan and then involving stakeholders to collaborate within these frameworks. "Complex social dynamics, such as trust building and power relations, have often been underestimated and the view of social relationships simplified" (Folke et al. 2005).

In the disaster situation where the community starts to self-organise, the government or emergency and disaster responders are not in control and dictating the communication flow of the event. This reaction from the community on the disaster is fuelled by their need for survival.

Edelenbos et al. (2018) define self-organisation as a concept deduced from systems thinking where new structures form out of chaos in order to create a new equilibrium. In addition the development of social media and communities engaging with the media, further challenges and disrupts the organised disaster management system in an effort to create equilibrium for the communities from 
their point of view (Nan and Lu 2014). This could explain the move away from a centralised to spontaneous online activity, as a desperate measure for the community system to reach equilibrium through an orderly response. Arendt and Alesch (2015) agrees by arguing the need for communities to be self-organising and adaptive social systems.

Particularly interesting is to note the perseverance and commitment of the community members driving these efforts. Edelenbos et al. (2018) hinted that the organisers need to have a certain "...personality and tactical flexibility".

In contrast to the community actions, governments find it challenging to secure the long term participation of communities in DRR efforts in preparation for a disaster ( $O^{\prime} B$ rien et al. 2012). Additionally, the complexity of the division of responsibility among agencies and governmental levels involved in a disaster, challenge the productive involvement of the community (Managi and Guan 2017).

Spialek et al. (2016) argues that this focus on resilience in particular, creates opportunities for communication practitioners and scholars, as assistance with strategies to engage and build relationships with communities becomes increasingly important. This paper furthers the above argument to show that communication management can also contribute to community communication and collaboration during the disaster, by utilizing the community's communicative resilience.

Communication management literature advocates a pro-active approach to communication planning, combined with an inclusive stakeholder perspective that encourages collaboration and power sharing (Grunig et al. 2002; Steyn and Puth 2000). Stakeholder relationship management theory suggests that through transparent and ethical communication mutually beneficial, long-term relationships that balance the interests of all parties, and share power, can be built (Grunig et al. 2002). Similarly communication management advocates proactive stakeholder relationship building in an effort to build strong relationships built on trust, commitment and control mutuality as defined by Hon and Grunig (1999) and which can survive a pressured environment.

Communication practitioners could advice disaster management on how to create the elements of trust in a relationship by enhancing integrity, dependability and by showing competence. Particularly in disaster situations where the governmental abilities could be limited due to various reasons, the community is most strongly waiting for a show of competence and in its absence, will self-organise. 
The benefit to the stakeholder, as much as to the organisation, is considered an important outcome of the communicative effort (Ledingham 2003). It is argued that these foci can contribute greatly to the DRR field (Le Roux 2013; Le Roux 2014). However, accountability and guidelines for possible lifethreatening outcomes of the shared communicative efforts, as found in the disaster management arena, is less clear.

\section{Guiding documents and frameworks}

To assist and guide disaster management actions by governments, there are four global guiding frameworks applicable to this study, namely The Sendai Framework for Disaster Risk Reduction, the Hyogo Framework for Action (HFA), The UN's Resilient Cities Programme and The GNDR Indicators of Good Local Government. Overall these guidelines seem to suggest a focus on pre-disaster and/or post-disaster collaboration with communities. The in-disaster communicative value of the community is not clearly stipulated.

The guiding document in the disaster risk reduction field, The Sendai Framework for Disaster Risk Reduction 2015-2030 (UNISDR 2015), suggests a strong focus on pre-disaster cooperation between government and other stakeholders on issues like structures and policies. The aim of the collaboration is suggested to be on the creation of collaborative structures and policies in preparation for a disaster (UNISDR 2015). The Framework advocates that the particular government involved retain overall responsibility and accountability for the management of the disaster, thereby cementing their communicative power.

The predecessor of the Sendai Framework, the Hyogo Framework for Action (HFA), focuses strongly on the local application of disaster risk measures by appealing to governments to "...enhance and support disaster risk assessment and related processes" (UNISDR 2005). Both frameworks are supported by 180 countries under leadership of the United Nations. Although advocating a proactive approach, guidance on in-disaster community communication is not given.

The UN's Resilient Cities Programme provides a ten-point checklist to guide local government on community engagement. The checklist focusses on pre-disaster and post-disaster actions. It suggests that DRR should be based on community participation and that governments must build local alliances. Post-disaster governments are urged to put community needs at the centre of reconstruction (UNISDR 2012). The Global Network for Disaster Reduction (GNDR) indicators of good local government suggest that citizens should have insight into their DRR efforts through advisory 
boards. It also suggests that government should: "Promote active participation [in DRR] by assigning particular roles and responsibilities to each group of stakeholders involved" (Nahem 2009). In both cases the in-disaster value of community communication needs more attention.

In practice, the Incident Command System (ICS) is used as a globally recognised disaster management coordination system by various countries such as the USA, UK, Australia and recently adopted in South Africa (WCG 2013). The system is seen as a management method that brings stability in a disaster by coordinating all activities on behalf of the responsible government. The ICS extensively guides the communication during a disaster, and encourage communication from the ICS team to outside stakeholders through roles like the liaison officer. ICS planning does not currently allow for the community affected by the disaster to spontaneously manage a section of the ICS functions (like communication), unless it was pre-planned and integrated into the ICS system expost, and community members has to be trained in ICS (FEMA 2017).

Becker and Van Niekerk (2014) argue that although the South African disaster risk governance is one of the most forward thinking in the world, the execution of these frameworks are lacking. Van Niekerk $(2014 ; 2015)$ adds that in particular there are no clear practical guidelines for the lower levels of government (municipalities), who are in direct contact with the affected communities, when there is a need for "...strong community engagement" (Van Niekerk 2015). In addition, the South African Disaster Management Act No 57 of 2002, only encourage volunteer action if training was given before the disaster and the volunteers are willing to work in a structured environment. It is also suggested that municipalities should carefully manage the possibility of spontaneous and uncontrolled volunteer action.

The Amended Disaster Management Act (2015) has a stronger focus on community inclusion when referring to emergency preparedness, and expects Disaster Management to show how communitybased adaptation approaches will be included in their disaster management plan. There is no further clarity on how the spontaneous organising community can be included in the in-disaster scenario, with a push for the disaster management centres to plan for such behaviour in advance. 


\section{Context of the study}

Knysna is part of the tourist area, the Garden Route, in South Africa. From the 7 June 2017, for more than two weeks, a fire fuelled by storm winds raged, leading to the largest mobilisation of South African firefighters in the country's history (De Villiers, 2017). At times more than 26 separate fires were burning concurrently. More than 1100 houses were destroyed, with a further 385 houses and 69 schools left damaged by the fire. The death toll amounted to nine people. The South African National Defence Force provided 150 troops as security for vacated properties that could be looted, and to assist in water-bombing operations (BBC, 2017). In total 11 Oryx helicopters were used for water bombing at a cost of R13 million $(\approx f 650000)$ because the typography of the landscape added to the complexities of fighting the fires.

The road leading into and out of Knysna had to be closed, making rescue and relief access almost impossible (Anon, 2017; Clarke and Joseph, 2017; Vegter, 2017). Some residents that were trapped by the fire, were moved by the National Sea Rescue Institute and volunteers via the sea to safety, whilst others sheltered on the beach. In addition to evacuating private residences, old age homes, hospitals and tourist accommodation also had to be evacuated.

In the chaos that ensued, communication cables and towers, and electricity cables were destroyed within the first few hours of the disaster, which disrupted municipal disaster communication to the community (Vegter, 2017). This rendered only social media and applications, like WhatsApp and Facebook, as communication tools.

The Knysna Fire was classified as a disaster in its early stages, and as such the government had to take the lead and responsibility in the disaster management efforts by means of the actions of the Disaster Management Centre and municipalities involved.

The government structures involved in this disaster was the Western Cape Provincial Government, the Eden District Municipality, and the Knysna Local Municipality. At the time of the Knysna Fire, the Western Cape Provincial Government was facing six further disasters including local service delivery protests and a severe drought.

A few days before the fire, a strong winter storm hit the municipality with high winds, lightning, and rough seas, which resulted in collapsing homes, fires and fatalities (BBC 2017). The storm hit Cape 
Town first and then continued to batter the rest of the municipal area. The strong winds from this storm played a significant role in the Knysna Fire disaster (Aljazeera 2017). At the time of the storm, approximately 10000 people, out of a population of 77000 , had to be evacuated from their homes in Knysna (BBC 2017). A government facing more than one disaster, with limited communication capability, seems to be the scenario that municipalities have faced before during disasters, and such a situation is frequently described in DRR literature.

The disaster management centre for the Knysna area, is situated in the Eden District Municipality, which is located in George, a town close to Knysna. The Knysna Local Municipality played a key role in the Knysna Fire Disaster, as they were closest to the communities involved.

\section{Research method}

A phenomenological approach was used in order to understand the lived experience from those involved in managing and co-ordinating the community social media reaction to the 2017 Knysna Fire Disaster, in order to extract the universal characteristics of the phenomenon (Hillman and Radel 2018; Taylor et al. 2015).

A qualitative research strategy allowed the research sufficient flexibility to explore the topic under investigation, understand the complexities of the situation, and provide sufficient information to answer the research questions. In particular semi-structured interviews, content analysis and participant observation was used. Using these flexible and dynamic research methods allowed the researcher sufficient time to explore the research topic to produce descriptive data that develop insight on how people acted and thought, as well as take practical considerations of accessing people otherwise not available, into account (Taylor et al. 2015).

The research approach and strategy dictated that a small number of information rich participants were needed that could provide insight into the research topic (Hillman and Radel 2018; Taylor et al. 2015). The interview schedule was conducted based on the themes identified in literature. The semistructured interviews allowed for questions to be rephrased and further delve into detail as necessary. The interviews provided sufficient data and reached data saturation (Taylor et al. 2015). The interviews were conducted in August 2017, just more than 2 months after the fire, which ensured that the experience was still vivid in the interviewees' minds. 
The interviewees included the Disaster Manager, Communication Manager, two Communication Officers and two Communication Interns who formed the communication team that worked on the disaster from the Eden Municipality. The Communication Officer from the Knysna Municipality was also included as the main source of information from this municipality to the community. All those with responsibility for communication during the disaster from municipal and district municipality level were included in this sample. Qualitative studies does not require large sample as the depth of the data provides the richness that is sought for insight. The interview data was analysed through thematic analysis. The themes were distilled from the data and within the larger framework of the literature conceptualisation.

To incorporate the view from the community, in-depth interviews with the two community members that originated a Facebook page central in self-organising the community, was done. In addition, content analysis of the first month's (June-July 2017) content on this Facebook page was included. The content analysis provided triangulation with the data given by the community interviewees, and supported the findings as interpreted from the community's point of view.

The researchers also attended the debriefing of the disaster from 31 July to 1 August 2017 held in Cape Town, organised by the Western Cape Provincial Disaster Risk Management Centre, to further understand the context of the disaster. Various players that were involved in the disasters managed by this specific disaster management centre, presented their insights with panel discussions and conversations. As participant observers the researchers were able to gain a greater understanding of the complexities of the situation and context of the disaster that assisted in the interpretation of the results (Hillman and Radel 2018).

\section{Findings}

The findings will be discussed according to the themes identified in literature.

\section{Challenges in disaster management as motivation for community self-organisation}

From a DRR view that advocates pro-activeness and a structured approach to managing a disaster, it was clear that the Knysna Local Municipality was under immense strain during the disaster. In a disaster like the Knysna Fire, the Local Municipality may opt to manage the disaster from their own local JOC with support from the District Municipality, which was done in this case. This decision 
could be argued to have political influence as the municipality could show their worth. Although having the JOC closer to the disaster to facilitate quicker firefighting reaction could have been argued to negatively impact communication to the community, as the municipalities limited communication resources were even further stretched. Facing issues such as limited capabilities during a disaster is expected, however, it motivates the need for greater community action for resilience, as motivated by authors such as Edelenbos et al. (2018), Nan and Lu (2014) and Theocharis et al. (2017).

The municipalities managed the disaster from the regulatory guidance given, but faced practical difficulties in collaborating with the spontaneous self-organising community. Especially given that the way in which the community self-organised could not have been predicted in advance. The community members who ran the Facebook page admitted that it would not have been something they would have considered beforehand. Therefore, even the requirements from the Amended Disaster Management Act (2015) to proactively plan for such events, in practice, was challenging.

\section{Challenges for communication management as motivation for community self-organisation}

Regarding communication channel management and information flow, the Western Cape Local Government specifically remarked on the importance of using both traditional and social media in combination during disasters. The Local Government reiterated the importance of early warning messages to communities and that two-way information flow, without referring to it being symmetrical or not, should be encouraged. However, they confirmed that in practice these ideals were hard to reach due to the challenges experienced during the disaster.

The Local Municipality faced serious communication challenges from very early on in the disaster. Their usual communication channels included a presence on Facebook, Twitter and a Municipal App. However, when all telephone communication were lost early in the disaster, the municipality had to ask the community to contact them by sending messages through Facebook Messenger as emergency response. These messages were then relayed to the JOC (Joint Operations Centre) manually. After a decision was made for action by the JOC, the written message was fed back to the community member via Facebook Messenger. The communication practitioner mentioned that "...social media was going crazy...", as they tried to manage the situation. From a disaster management perspective this was problematic as there would be no clear record of disaster related calls and actions, impacting on accountability. This in return would negatively impact the community's view of municipal competence (Hon and Grunig 1999). 
The municipal communication teams had to respond to a large number of media and other messages and facilitate numerous queries. This kept them from initiating information on logistical arrangements for relief donations and this information was only made available from 3 days after the disaster. In addition, the disaster management team first priority was to contain the disaster and information on a clear procedure for the handling and monitoring of donations was not immediately made available. As indicated before, this once again allows room for the community to self-organise.

Although communication professionals took the lead for communication during the disaster, the challenges they had to overcome severely impacted their ability to showcase their strategic worth.

The Disaster Management Centre located at the Eden District Municipality, makes use of the communication services of the district municipal communication practitioners. These practitioners have to continue with their day-to-day job and facilitate the disaster communication. In addition, the communicators were not specifically trained in the ICS system used. However, they do know that communication should be involved from a very early stage in the disaster and play a central role in contributing to response, rescue and recovery. Both the Centre and the practitioners tried to be as proactive as possible within the constraints they experienced.

At the time of the disaster the Local Municipality did not have an appointed Communication Manager, and the Communication Officer was assisted by a Communication Intern. When keeping in mind the amount of information that needs to be communicated during a disaster, the municipality needed communicative support.

From the interviews it was clear that both municipalities and in particular the communication practitioners was under immense pressure during a situation that was foreign to them, and which combined the worst case scenarios in terms of losing established means of communication with stakeholders.

On a positive note, the practitioners remarked that the disaster lead community members not active on social media to become active participants as a result of the disaster. The local municipality's Facebook page numbers increased from 5000 to 10000 members during the disaster. 


\section{Profiling the lead community members}

Before the disaster the husband and wife team that set up the Knysna Fire 7 June 2017 Facebook page, was well ingrained in the Knysna society and included in various WhatsApp groups for the area, specifically a women's WhatsApp group that also included the mayor. They have business interests in the area and showed clear commitment for the area and community to thrive.

Their actions to create a Facebook page came from them wanting to make a contribution during the disaster in order to assist the community. They realised that there was a need to consolidate information from various Facebook, Twitter and WhatsApp groups, to a centralised place for the community to be able to access information in a more structured way. This aligns clearly with the view that the community was trying to reach equilibrium in a chaotic environment (Arendt and Alesch 2015; Nan and Lu 2014).

Apart from coordinating disaster related information, the team also tracked financial donation schemes that were set up on social media pages, due to the risk of opportunistic individuals trying to exploit on the situation. They asked pages like Back-a-Buddy to verify the intentions of those that created the requests and "...some of the pages were taken down as they were found to be bad guys."

In agreement with Edelenbos et al. (2018), the lead community members were able to, under great pressure, to be flexible in working with various parties to collate information, and showed unique personal characteristics such as commitment, an embedded interest, dedication and a strong moral obligation. Through communication, the actions from a few individuals were able to improve the resilience of a larger community, by enabling the community to adapt to the event (Villagra \& Quintana 2017).

\section{A description of communicative self-organisation by the community}

The Knysna Fire 7 June 2017 Facebook page is an artefact that represents community's striving for resilience during a disaster.

Both the interview with the community members and Facebook analysis confirmed that the in the first 3 days the page focussed most on relaying information from people on the ground, directing firefighters, evacuation messages, distress calls, updates on fire spread, and posts on animal welfare. Some information on disaster aid and relief coordination of distribution points were noted. 
On the second day, posts focussed on the above and also messages of support for those affected by the disaster, sharing messages, photos and official letters. On the third day posts highlighted information on fires that were still burning, coordinating donations and relief aid, reuniting owners and pets, searches for missing persons, and organising and bringing together people wanting to volunteer. Practical information on immediate assistance people could get from insurance companies was also shared, together with contact details of the municipality. At this point the Airbnb disaster tool was also activated. On the Facebook page appreciation for firefighters are also shown and received great reaction. Another favourite was the map updates that were created by volunteers on the ground in the area.

After 2 weeks the page turned more to donation and relief coordination to show the community needs. There was also a strong focus on messages of hope and future activities and tourist incentives to rebuild the area. The page also provided a space where people could discuss reports on the fire candidly.

Through their own research the respondents suggested that many relief organisations reacted from information on their page, without being active on the page. In addition they found that a large number of the donations received, were made based on what people saw on the Facebook page. As shown by the respondents, impact of immediate and clear communication during a disaster, cannot be emphasised strongly enough.

The respondents set up a trust account to which donations could be made and in which people could specify the goals that the donation needed to be used for. They regularly reported on the progress of this account and the bank statements were regularly made available on their Facebook page.

\section{Community self-organising influence on stakeholder relationships}

The respondents were keen to verify information with the JOC before posting it on their Facebook page and engage with the municipality, but found the process to slow and cumbersome and proceeded without JOC approval. The relationship between the municipality and community groups deteriorated as the disaster progressed and the respondents were informed that the municipality were "...not happy about the page".

The municipality took note of the social media pages initiated by the community over which they had no control. They however, stated strongly that it was seen as their responsibility to organise the 
rescue and relief effort with the community organisations involved, by being the link between donations and receivers, as per the Disaster Management regulations.

The result was that both parties in the strained relationship to some extent stopped involving the other in their communication attempts stifling all collaboration. Although Edelenbos et al. (2018) argued that they found governments to be positive about community self-organisation initiatives, it was not the case in this instance. This could be attributed to various issues, such as the pressure under which the municipalities had to operate, the lack of clear guidelines on how to involve spontaneous community self-organisation while still retaining the responsibility, or historical mistrust in the relationship.

Interestingly in this case the community members were more positive than the governmental entities to have a collaborative relationship during the disaster. The respondents suggested that having community members involved in communication coordination could assist the municipalities, as the community members can "...work around red tape, where the municipality cannot".

The respondents suggested that it was in the disaster management team's interest that community members had vested interest in good communication flow during the disaster. The respondents found that trust could also be created in messaging as the information is found to be timeous, helpful and accurate.

\section{Speed at which in-disaster communication needed to flow}

Although it is agreed that communication should flow fast from the disaster managers to those affected, the speed and vastness of information flow has not been specifically mentioned in literature.

During this disaster the communication flow at Local Municipality level seemed particularly slow, due to the process that had to be followed. The Joint Operations Centre (JOC) needed to meet and then a situational report was produced from which the media, and through the media, other stakeholders were informed twice daily.

To reach the local community the municipal communication practitioner noted that information changed rapidly and that social media had to be updated "...every 10 minutes..." with new information. The municipality did not have any social media software to assist them in managing the situation. 
The community's view on the speed at which new information needed to be circulated was different from that suggested by the municipalities. The community argued that the need for regular updates was necessitated by the constantly changing disaster situation.

The amount of information posted to the centralised Facebook Page was vast. One respondent noted: "...at the start of the disaster the page was updated every 30 seconds to 1 minute, with more than 640 posts for the first day alone". Up until day 40 they posted more than 2500 times. The volume was so great that it alerted Facebook and the posts were taken down. The respondents had to contact Facebook to explain the situation to be able to continue sending out information. Due to this some of the initial posts could not be retrieved for analysis.

In addition, the respondents dealt with more than 1500 Facebook Messenger messages a day, over and above the WhatsApp calls and messages they received.

It is clear that the vast task of sending timeous information out during a disaster, would be difficult for a disaster management team that might already be under pressure due to various other challenges they are facing. It would seem that there is a ripe opportunity for communities to assist in this sphere of disaster management by spontaneously self-organising disaster related communication, preferably in collaboration with the disaster management actions.

\section{Discussion, recommendations and conclusion}

The study reiterated what was found in previous studies: that communities will strive to survive disasters (Hobfoll 2012, in Williams and Sheperd 2016).

One of the main contributions of this research is that it gives one of the first clear indications of the speed and scope of communication needed during a disaster. The finding further suggests that the communication expectation during a disaster is much bigger than previously anticipated. If assumed that messages need to be sent out every 30 seconds to a minute, it becomes clear that a very robust, proactive communication team and communication channels needs to be in place and trained before a disaster. It remains problematic that the messages need to be sent out quicker than what the JOC process and disaster management process can facilitate. It would seem that the development of spontaneous communicative self-organisation of communities could possibly relate 
to this challenge. However, these community groups could also be an untapped resource for disaster management teams, given that a way of working together where accountability according to the regulatory frameworks stays with the governmental institutions, can be found.

Various challenges to disaster management was mentioned. The study highlighted the need for a robust, trusting relationship between municipalities and communities before a disaster hits. It seemed that there were little understanding between the municipality and community in terms of their roles and responsibilities during the disaster, which proved detrimental to their relationship. The community interpreted the lack of information from the government as a lack of involvement and willingness to assist. The municipalities also did not expect that communities could contribute to the disaster management effort, leading to them trying to gain control offer the community's selforganisation efforts. These views negatively influenced the trust relationships and the disaster management efforts.

From the research it can be argued that the characteristics of such community leaders should display a motivation for resilience creation for the whole community. This highly motivated resource need to be recognised.

Communication professionals could play a positive, strategic role in guiding relationship building as preparation for disaster management and part of increasing community resilience (Gupta 2012). Such activities would align with the guidelines from the Amended Disaster Management Act (2015). The recommendations from this study includes that a proactive approach to the phenomenon needs to be developed and followed. This proactive approach would unfold on two levels:

- Firstly, on DRR policy and framework level, the willingness and ability of community volunteers to assist with communication actions during a disaster should be acknowledged. The Amended Disaster Management Act 2015 to some level hints toward this, but still does not provide best practice guidelines. Frameworks and standards for the management of disasters should incorporate the opportunity for community members to spontaneously contribute during the disaster, and not only in resilience building before, or rehabilitation efforts after the disaster. Providing formation on this issue, and adding more research to highlighting the phenomenon to the UNISDR, could see it taken up into the next Framework for DRR. On an operational level, the ICS system could be expanded to allow for community 


\section{Research limitations and suggestions for future research}

Bean (2018) motivates for research on communication in disasters as "vitally needed", and argues that the results can contribute to further community resilience. Although this study only focussed on one disaster, the trend of the disaster "victims" providing a valuable communication resource need to be further explored to provide clear policy frameworks and best practice.

Future studies could compare various examples of community self-organisation of communication during disasters, and test best practice suggestions to reach a prescribe code of practice. Including large scale studies viewing this phenomenon from a community perspective would similarly 
illuminate the constraints of those affected by disasters and their motivation for action and selection of action routes to take. Network theory could also be used to understand the spontaneous development of community leaders that drive community self-organisation efforts. 


\section{References}

Aljazeera. (2017), "Storm kills several, displaces thousands in Cape Town", available at:

https://www.aljazeera.com/news/2017/06/storm-kills-displaces-thousands-cape-town170608052748704.html (accessed November 12, 2017).

Al-Taie, M.Z. and Ali, A. (2017), "A self-organizing communication model for disaster risk management", International Journal of Advanced Soft Computing Application, Vol. 9 No. 2, pp. 1730.

Anon. (2017), "About: The Garden Route Rebuild", available at:

https://www.gardenrouterebuild.co.za/about/(accessed November 12, 2017).

Arendt, L. A., \& Alesch, D. J. (2015). Long-Term Community Recovery From Natural Disasters, CRC Press, Boca Raton.

BBC. (2017), "South Africa: 10,000 Knysna residents evacuated amid fire", available at: https://www.bbc.co.uk/news/world-africa-40199270(accessed November 12, 2017).

Bean, H. (2018), "National resilience", Journal of Applied Communication Research, Vol. 46 No 1, pp. 23-25.

Becker, P. and Van Niekerk, D. (2014), “Developing sustainable capacity for disaster risk reduction on Southern Africa", in Schroder, J. Hazards, Risks, and Disasters in Society, Elsevier, Amsterdam, pp. 63-78.

Clarke, H. and Joseph, E. (2017), "Unprecedented' bush fires in South Africa leave 9 dead", available at: https://edition.cnn.com/2017/06/08/world/south-africa-fires/ (accessed November 12, 2017).

Cole, J.M. and Murhpy, B.L. (2014), "Rural hazard risk communication and public education: Strategic and tactical best practices", International Journal of Disaster Risk Reduction, Vol. 10, pp. 292-304.

Concern Worldwide. (2015), “Disaster Risk Reduction for Community Resilience: A synthesis of lessons from more than a decade of Disaster Risk Reduction Programming", available from: 
https://doj19z5hov92o.cloudfront.net/sites/default/files/resource/2015/12/disaster risk reduction for community resilience.pdf (accessed November 12, 2017).

Coombs, W.T. (2015). Ongoing crisis communication: Planning, managing and responding, Sage, Thousand Oaks, California.

De Villiers, J. (2017), “Knysna fire led to largest deployment of firefighting resources in SA history authorities", available at: https://www.news24.com/SouthAfrica/News/knysna-fire-led-to-largestdeployment-of-firefighting-resources-in-sa-history-authorities-20170620 (accessed November 12, 2017).

Delicia-Willison, Z. and Gaillard, J.C. (2012), "Community action and disaster", in Wisner, B., Gaillard, J.C. and Kelman, I, The Routledge Handbook of hazards and disaster risk reduction, Routledge, Oxon, pp. 711-722.

Edelenbos, J., Van Meerkerk, I. and Koppenjan, J. (2017), "The challenge of innovating politics in community self-organization: the case of Broekpolder", Public management review, Vol. 19, No. 1, pp. 55-73.

Edelenbos, J., Van Meerkerk, I. and Schenk, T. (2018), "The evolution of community self-organization in interaction with government institutions: cross-case insights form three countries", American review of public administration, Vol. 48, No. 1, pp. 52-66.

FEMA. (2017), “National Incident Command System”, available at: https://www.fema.gov/medialibrary-data/1508151197225-ced8c60378c3936adb92c1a3ee6f6564/FINAL NIMS 2017.pdf (accessed November 12, 2017).

Folke, C., Hahn, T., Olsson, P. and Norberg, J. (2005), “Adaptive governance of social-ecological systems", Annual Review of Environmental Resources, Vol. 30, pp. 441-473.

Grunig, L.A., Grunig, J.E. and Dozier, D.M, (2002), Excellent public relations and effective organizations: a study of communication management in three countries, Lawrence Erlbaum, Mahwah, NJ. 
Gupta, M. (2012), "Settlement and shelter reconstruction", in Wisner, B., Gaillard, J.C. and Kelman, I, The Routledge Handbook of hazards and disaster risk reduction, Routledge, Oxon, pp. 553-565.

Hillman, W. and Radel, K. (2018), Qualitative methods in tourism research: Theory and practice, Channel view publications, Bristol.

Hon, L.C. and Grunig, J.E. (1999), Guidelines for measuring relationships in public relations, Institute for Public Relations (IPR), available at https://instituteforpr.org/measuring-relationships/ (accessed November 12, 2017).

Jiang, Y. and Ritchie, B.W. (2017), "Disaster collaboration in tourism: Motives, impediments and success factors", Journal of Hospitality and Tourism Management, Vol. 31, pp. 70-82.

Le Roux, T. (2013), "An exploration of the role of communication during the in-crisis situation", Jàmbá: Journal of Disaster Risk Studies, Vol. 5 No. 2, pp. 1-9.

Le Roux, T. (2014), "DR ${ }^{4}$ communication in the South African context: A conceptual paper", Public Relations Review, Vol. 40 No 2, pp. 305-314.

Ledingham, J.A. (2003), “Explicating relationship management as a general theory of public relations", Journal of Public Relations Research, Vol. 15 No. 2, pp. 181-198.

Managi, S. and Guan, D. (2017), "Multiple disasters management: Lessons from the Fukushima triple events", Economic Analysis and Policy, Vol. 53, pp. 114-122.

Nahem, J. (ed). (2009), “UNDP: A user's guide to measuring local governance”, available at: http://www.undp.org/content/dam/aplaws/publication/en/publications/democraticgovernance/dg-publications-for-website/a-users-guide-to-measuring-local-governanceLLG\%20Guide.pdf (accessed November 12, 2017).

Nan, N. and Lu, Y. (2014), "Harnessing the power of self-organization in an online community during organizational crisis", MIS Quarterly, Vol. 38, No. 4, pp.1135-1157, Dec. 
Ng, S. (2016), "Governance beyond the government: responding to a reactionary flood governance regime in Ayutthaya, Thailand", Habitat International, Vol. 52, pp. 11-19.

O’Brien, G., Bhatt, M., Saunders, W., Gaillard, J.C. and Wisner, B. (2012), “Local government and disaster", in Wisner, B., Gaillard, J.C. and Kelman, I, The Routledge Handbook of hazards and disaster risk reduction, Routledge, Oxon, pp. 629-640.

Pitt, C.S. and Treen, E. (2016), "Understanding communication in disaster response: A marketing strategy formulation and implementation perspective", Journal of Public Affairs, Vol. 17 No. 3, pp. 17.

Shkaruba, A., Skryhan, H. and Kireyeu, V. (2015), "Sense-making for anticipatory adaptation to heavy snowstroms in urban areas", Urban Climate, Vol. 14, pp. 636-649.

South Africa. (2002), Disaster Management Act, 2002 (Act 57 of 2002), Government Printer, Pretoria.

South Africa. (2015), Amended Disaster Management Act, 2015, Government Printer, Pretoria.

Spialek, M.L., Czlapinski, H.M. and Houston, J.B. (2016), "Disaster communication ecology and community resilience perceptions following the 2013 Illinois tornados", International Journal of Disaster Risk Reduction, Vol. 17, pp. 154-160.

Steyn, B., and Puth, G, (2000), Corporate communication strategy, Heinemann, Sandown.

South Africa (Republic). (2002). Disaster Management Act 57 of 2002. Pretoria: Government Printer.

Taylor, S.J., Bogdan, R. and De Vault, M.L. (2015), Introduction to Qualitative Research Methods: A Guidebook and Resource, John Wiley \& Sons, Hoboken, New Jersey.

Theocharis, Y., Vitoratou, S. and Sajuria, J. (2017), "Civil society in times of crisis: understanding collective action dynamics in digitally-enabled volunteer networks", Journal of Computer-Mediated Communication, Vol. 22, pp. 248-265. 
UNISDR. (2005), “Hyogo Framework for Action 2005-2015: Building the Resilience of Nations and Communities to Disasters", available at:

https://www.unisdr.org/files/1037_hyogoframeworkforactionenglish.pdf (accessed November 12, 2017).

UNISDR. (2012), "The Ten Essentials for Making Cities Resilient Checklist Summary", available at: https://www.unisdr.org/files/26462 13.tenessentialschecklist.pdf (accessed November 12, 2017).

UNISDR. (2013), "United Nations Plan of action on disaster risk reduction for resilience", available at: https://www.preventionweb.net/files/33703 actionplanweb14.06cs1.pdf (accessed November 12, 2017).

UNISDR. (2015), "Sendai framework for disaster risk reduction 2015-2030", available at: https://www.preventionweb.net/files/43291 sendaiframeworkfordrren.pdf (accessed November 12, 2017).

UNISDR. (2017), "Terminology", available at:

https://www.unisdr.org/we/inform/terminology\#letter-d (accessed November 12, 2017).

Van Niekerk, D. (2014), "A critical analysis of the South African Disaster Management Act and Policy Framework", Disasters, Vol. 38 No. 4, pp. 858-77.

Van Niekerk, D. (2015), “Disaster risk governance in Africa: A retrospective assessment of progress against the Hyogo Framework for Action (2000-2012)", Disaster Prevention and Management, Vol. 24 No. 3, pp. 397-416.

Vegter, I. (2017), "Devastation in Knysna: a photo survey", available at:

https://www.dailymaverick.co.za/article/2017-06-09-devastation-in-knysna-a-photosurvey/\#.WzDydVVKiUk (accessed November 12, 2017).

Villagra, P. and Quintana C. (2017), “Disaster governance for community resilience in coastal towns: Chilean case studies", International journal of environmental research and public health, Vol. 14, No. 1063, pp.1-24. 
Western Cape Government (WCG). (2013), "Overview of the Incident Command System", https://www.westerncape.gov.za/text/2013/June/incident-command-system-overview-20-june2013.pdf (accessed November 12, 2017).

Williams, T.A. and Sheperd, D.A. (2016), "Victim entrepreneurs doing well by doing good: Venture creation and well-being in the aftermath of a resource shock", Journal of Business Venturing, Vol. 31, pp. 365-387. 